\title{
Students' Perceptions of using Facebook in ESL Classroom
}

\section{Kasturi Rajagopal, Parilah Mohd Shah}

To Link this Article: http://dx.doi.org/10.6007/IJARBSS/v11-i11/11088

DOI:10.6007/IJARBSS/v11-i11/11088

Received: 04 September 2021, Revised: 06 October 2021, Accepted: 28 October 2021

Published Online: 17 November 2021

In-Text Citation: (Rajagopal \& Shah, 2021)

To Cite this Article: Rajagopal, K., \& Shah, P. M. (2021). Students' Perceptions of using Facebook in ESL Classroom. International Journal of Academic Research in Business and Social Sciences, 11(11), 1327 1349.

Copyright: (c) 2021 The Author(s)

Published by Human Resource Management Academic Research Society (www.hrmars.com) This article is published under the Creative Commons Attribution (CC BY 4.0) license. Anyone may reproduce, distribute, translate and create derivative works of this article (for both commercial and non-commercial purposes), subject to full attribution to the original publication and authors. The full terms of this license may be seen at: http://creativecommons.org/licences/by/4.0/legalcode

Vol. 11, No. 11, 2021, Pg. $1327-1349$

Full Terms \& Conditions of access and use can be found at http://hrmars.com/index.php/pages/detail/publication-ethics 


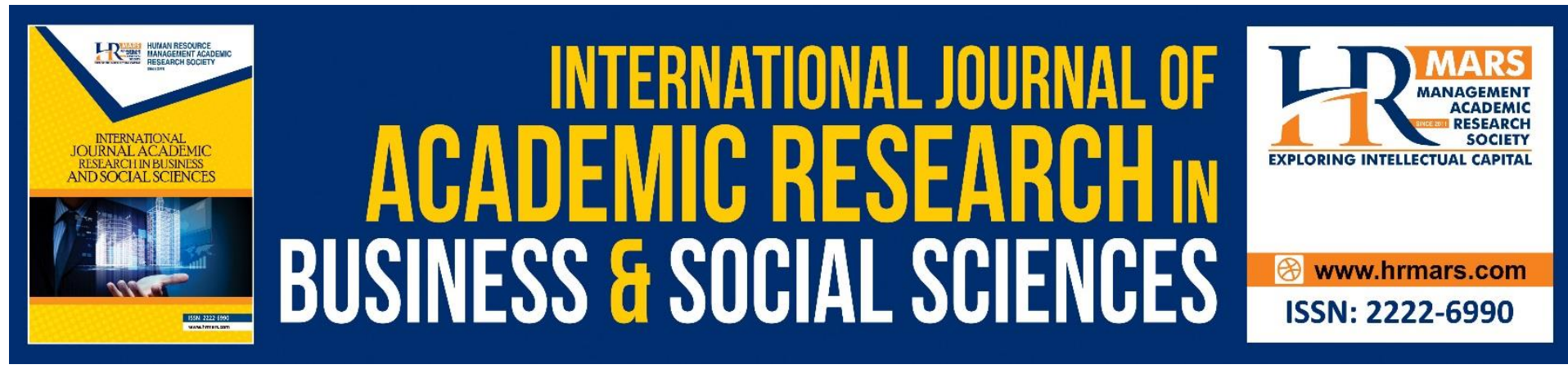

\title{
Students' Perceptions of using Facebook in ESL Classroom
}

\author{
Kasturi Rajagopal, Parilah Mohd Shah \\ Faculty of Education, Universiti Kebangsaan Malaysia (UKM)
}

\begin{abstract}
English has become a necessary part of daily life in the age of globalization. The importance of English in the educational system has been recognized by people across the globe. So, the utilization of Social Networking Sites in ESL classroom will be effective in achieving positive perceptions and attitudes toward language learning. Facebook is a widely used Social Networking Site because it has significant possibility of becoming useful resource in regards to assist their language learning in ESL classroom. This paper attempts to examine students' perception of using Facebook for English language learning in classroom and to inquire this Facebook site can aid language learning capabilities of students. This study also aimed to study students' perceptions of using Facebook in ESL classroom based on four elements, , perception of using Facebook for language learning, students' motivation, confidence level and attitude. The respondents of this study are 30 from an urban school located in Johor Bahru. The questionnaire was administered to explore students' perception and their attitude of using Facebook for language learning. This study revealed that ESL students perceive Facebook as a medium of e-learning that can enhance and supports the development of language skills. In addition, the result pertained that students' motivation and confidence enhanced in regards of English language learning. The study also demonstrated that students exhibit positive attitudes towards language learning. In conclusion, it is recommended that ESL teachers can employ Facebook site as learning tool of optimal English language learning. Keywords: Social Networking Sites (SNS), Facebook, Language Learning.
\end{abstract}

\section{Introduction}

\section{Background of the Study}

Social media is a foremost part of humans' life in this fast-paced era. In today's technologically-developed culture, most of the individual use some sort of social media for different purposes. According to Pew Research Center study conducted on 2018, about $88 \%$ of respondents between the ages of 18 to 29 reported employing some sort of social media in a daily basis. Social media has become an important tool to attain people's attention. According to Shin (2018), people use social media for many purposes, such as finding information, maintaining friendships, and expressing multiple identities. Tess (2016) quoted that social media are computer-mediated tools that give people opportunity for creating, sharing ideas each other, exchanging information and resources, sharing pictures or videos in virtual communities and networks through internet. 
Inayati (2015) stated that the nature of social media is in line with the implementation in education platform as it also facilitated the development of language acquisition theories. According to Shih (2011), the theory suggested that learning arise when influential social interactions and diverse points of view within the community of using social medias and its experiences takes place within individuals. This idea is applicable in accordance with social media usage in educational field. The socio-cultural theory suggests that long-term exposure of target language and involvement with it is essential for language learning purposes. Thus, the good exposure social media can be utilized as an outperforming media to implement English language learning activities in classroom.

Furthermore, the social media can be utilized for the development of language learning skills. Based on the study proposed by Yunus et al (2012), it evident that Facebook site will help learners to be accommodated with language input in line to enhance writing skill. The social media also leads learners to acquire new words and vocabulary to write. Social media also enhances students' capacity to learn and communicate through the interactions conducted with native English speakers (Ehsan \& Nasri, 2019). In addition, the social media also pertained to show potential in developing students' language skills. Arumugam et al (2019) argued that social media like Facebook and WhatsApp allows learners and educators to create a learning group for learning purposes. Sharing reading material, reading aloud practice, and discussing reading text activities enable learners to be actively participate in order to establish their reading skills. Meanwhile, content sharing media such as YouTube provide either in formal and informal use of English videos to practice listening skills.

From the perspective of communication to education, social medias serve as a collateral platform in understanding the content of learning in better ways. Social media intend to promote communication, information, sharing tools, educational resources, entertainment, and business purposes. It helps to converse and maintain good communication with individuals without brisking time and place limitation. Guedes et al. (2016) probed that social media leads faster interaction by observing and evaluating others' accomplished tasks using advanced features in each social media. They also smooth the virtual meetings and enables communication with others in line with the purpose of learning, casual communication or business purposes. The existence of digital appliances ad platforms make it comfort for people to retrieve a variety of data sources and get connected without limitation of time and place. Further internet technological appliance has feasible progress in the prevailing teaching methods, which will eventually steer towards the path of acquiring quality educational learning. Social media has its own range of advantages and appropriateness among the millennial generation. It is strongly recommended in educational arena by both learners and educators as it to improve and uphold the learning process.

Social media tools have high potential to affect students' second language learning in which it motivates learners to show active involvement in learning context. The evolution of social site appliances such as Facebook, Twitter, Instagram, Tik Tok, YouTube and other sites gained huge popularity from the users in worldwide. Buzzetto-More et al (2012) studied that the integration of social networking sites into education has improved students' learning interest in overall. The results of the study revealed positive outcomes and proved social networking sites inspired language instructors to to scrutinize new teaching methodologies to employ sites appropriately like Facebook and Instagram to enhance teaching approaches 
that lead to the enhancement of students' language learning skills. According to Mazman \& Usluel (2010), Facebook was established in 2004 and has grown in the best way possible to become as most well-known and influential social-networking tool in the world to pertain one's learning possibilities.

In Malaysia, Facebook is widely used and renowned social networking site in regards of various group of people. García-domingo et al (2017) also claimed that three out of four population of the world are actively engaged in Facebook platform as it possibly affirmed the claim of this social site. Moreover, students are prominent users of Facebook because technology has that potential to evolve as a reliable source to assist them in their studies. Alhomod \& Shafi (2012) proposed Facebook site as a medium for education in classroom learning, portrays its usages across every level in group learning and prompts interaction amongst students and teachers. Students' sturdy regards and active engagements towards this social media have appealed both practitioners as well as academic researchers awareness sight which they intend to create instructional activities for better language learning. AlMunawwarah (2014) revealed that the fusion of ICT element in educational learning can assist teachers to design and implement interesting and fun learning activities. In addition, information and communication technology promotes student autonomy and their motivation for learning.

In recent time, the world is facing COVID-19 pandemic and it had disrupted the learning processes in educational platforms. It changes the learning process which it lead to online learning. The educators use various strategies and social media applications in their teaching despite they did not know much about how their students use social media to improve language acquisition skills. In this matter, the educators need concerns about students' perception about learning ways and strategies which lend hand to teachers in creating teaching and learning activities for optimal learning.

Based on the explanation above, the investigation on students' perceptions in regards to the use of social media in acquiring English language is crucial for teachers to know their students' preferences about social media application they used and their ways of using social media to acquire English language in ESL classroom. Studies on exploring the perception of using Facebook conducted to provide valuable information about how students use social media, its benefit and ways of using Facebook application to learn English.

\section{Rationale of the Study}

The delivery of learning elements is changing alongside with the globalization in education which it had invented online-based learning and various educational approaches. These learning tools and approaches intend to arouse attention and students' interest to learn English even in the recent time without disruptions. Based on the demography data, it is found that Facebook site is the widely utilized socialization base in order to learn English among the respondents of this study. With the valid justification, the researcher intend to study about how the Facebook media is an effective tool to improve English language learning in a conducive ESL classroom. 


\section{Problem Statement}

Due to COVID-19 pandemic, the process of learning which held in the classroom changes into online learning. This study intended to identify students' perception of English language learning using Facebook helping teachers to design activities that gives impact in language improvement. Yunus and Salehi (2012) cited the utilization of Facebook in peer-topeer review is a method how learners review their peers' work based on the criterion derived by the educators. This process led to an escalation in students' interest rate and engagement during study. Furthermore, Kabilan et al. (2010) explained learners had acknowledged that their linguistic abilities developed through the continuum use of Facebook in learning, thus it boosted their enthusiasm, confidence, and attitude toward language acquisition through their experiences. These studies proved that Facebook site will assist learners to build their confidence, increase students' involvement and satisfaction in language learning process when this platform been utilized effectively.

Eren (2012) studied about interest and how the language learners pertained to use the language learning. The research portrayed the exhibition of students' positive attitudes toward Facebook for educational purposes and to enhance language skills. Numerous research studies have been proposed about Facebook's significant impact on motivation of students, contentment and learning attitudes. The current research intended to underpin this Facebook platform likely to explore students' discernment and perceptions in regards to the utilization of Facebook in ESL classroom learning. The teachers have been pointed with discovering information regarding the efficacy of Facebook site in educational proportion and seek strongest support for whichever action they decide in the basis of classroom learning. By focusing on learners' needs and desires and attribution to their attitudes, this study is proposed to determine how language learners perceived language learning component by using Facebook in classroom..

Based on the acclamation, teachers' acceptance on Facebook as an acquainted language learning tool require extensive information about how this site works best in the classroom. Thus, this study intended to discover these research questions;

a) What are the students' perceptions of using Facebook in ESL classroom?

b) What are the students' learning attitudes towards using Facebook in ESL classroom?

\section{Literature Review}

\section{Theoretical Framework of using Facebook for learning purposes}

The Theory of Facebook Usage for Educational Purposes theoretical model was chosen to structure this study. This is a constructional model that explicit how Facebook users can employ this site to empower their learning. Mazman \& Usluel (2010) structured this model with the connection of society and technology in Facebook as an innovative tool. The figure below depicts the conditional model proposed by Mazman and Usluel (2010) about the usage objectives and established procedures, adoption element, diffusion, recognition of Facebook in learning, theories related to the usages, and potential of existing features in Facebook for educational purposes. 


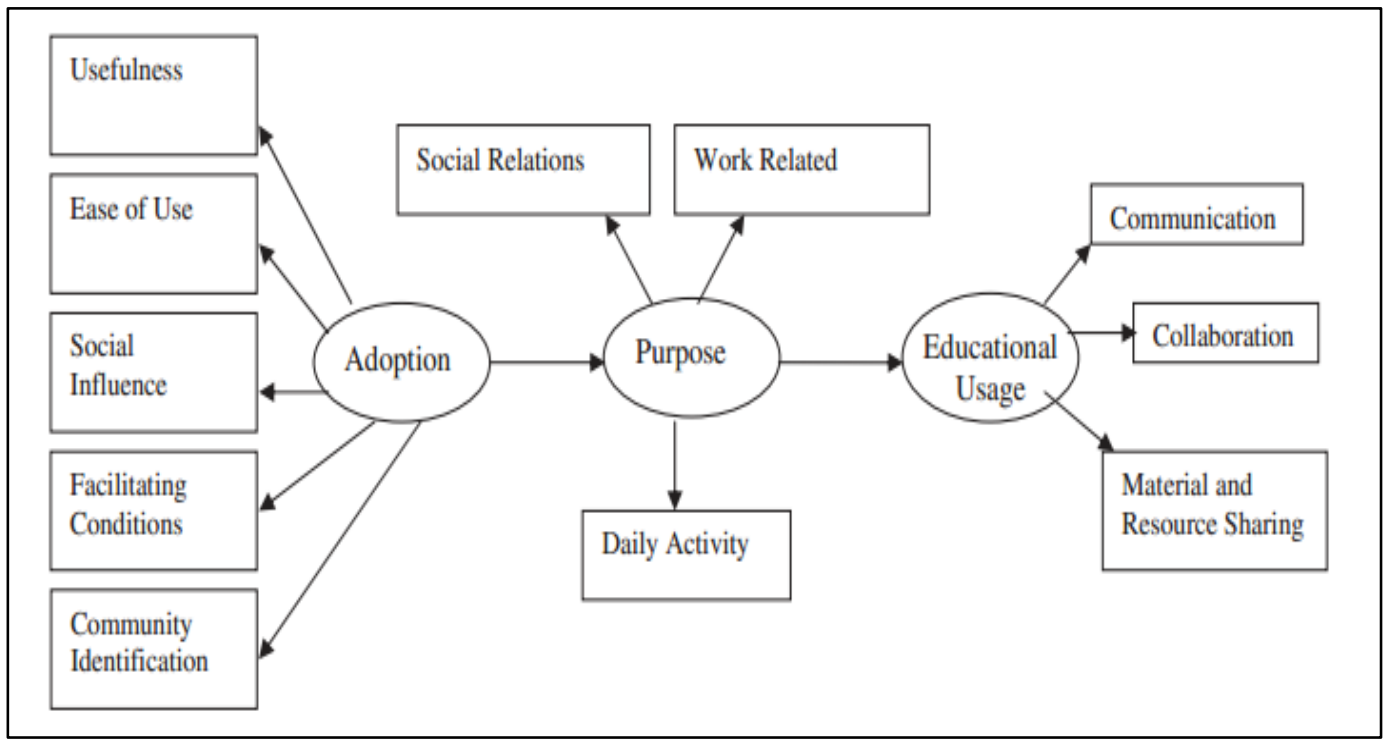

Figure 1 Model of using Facebook and Facebook Adoption for learning purposes (Mazman \& Usluel, 2010)

Data will be gathered via online mode. The questionnaire will probe about respondents' demographic details and student's perceptions and attitudes towards using Facebook in ESL classroom. The questionnaire is divided into few sections which examines students' demographic details, length of using Facebook application, perception of language learning, enhancing students' motivation, confidence level and also students' attitude towards learning English using Facebook through a set of Likert-type scale questions. The Likert-type scale questions were intended to prompt the urge of learning about how does the Facebook lead to an effective language learning in ESL classroom.

Mazman and Usluel (2010) pointed five observed variables, which is usefulness of Facebook application, ease of use, social influence, facilitating conditions and community identification variables to study the contribution of Facebook application for learning purposes. Workplace-setting and daily activities component had a tremendous impact on how the Facebook is adopted for educational purpose. The components in this model prompted a significant relationship about how an individual can perceive Facebook would affect and pertain educational benefits for users. Based on this model, Facebook adoption underpinned purposes-moderated of Facebook usage assimilated around $50 \%$ of the usage highlighting the learning possibilities been offered through the Facebook site. The educational opportunities offered through the site pertained the tendency to lead the learning in effective way help the learners to achieve the targeted objective as derived for particular learning sessions. Therefore, this model was employed as a reviewed framework for this study inhibition.

\section{Facebook as a Social Networking Site SNS}

Numerous studies have demonstrated the connection between SNS and language learning in useful context. The breadth of social media, channels, different precision of SNS have been inculcated in the usage of current trend. According to Aydin and Selami (2012), SNSs are online tenets availed by individuals which would fulfill the aim of developing and sustaining communal relations in conformity with personal interests and concerns in one's life. Boyd \& Ellison (2007) specifically quoted that SNSs are web-based tenets that proffer 
three main functions to users such as setting a public profile, initiating and keeping track of linkages with other users, comprising various features and gaining access to other links in the platform. Boyd and Ellison (2007) also defined that SNS can be used as social networking or online socializing base of action. The application of social site in education can be contemplated as the most crucial paradigm shifts in educational achievement (Arteaga et al., 2014).

In the midst of availability of various social media platform the researcher chooses Facebook social networking site as a tool of language learning development. Facebook site launched in 2004 by the founder Mark Zuckerberg when he was enrolled in Harvard University. The rapid growth of Facebook site intended researches about adopting and utilizing the site in various components from personalized inquiry, working, and social life. By offering the wide range of functionalities, Facebook site reflects current capabilities of social networking sites. It enable users to upgrade their personal profiles, making friends, exchange messages and media such as images, and to get organize into groups discussions in relation to professional and academic affiliations.

Apart from the functionalities, Facebook site also offers tools to produce multimedia contents like images, audios and videos. In the current pandemic swirl, Facebook is known as one of the easiest accessible platform to live-stream information regarding educational learning. In respect of education, particularly Facebook's enormous popularity in universities is thought to be on the level and transforming the ways students interact each other, work together and gain education particularly in universities. Blattner and Fiori (2009) proved that Facebook possess a high potential in line to progress social competency and build community. Facebook is knows as highly used media and a great asset to prop up educational communications and collaborations.

Eventually, social networking site can be utilized effectively to uphold useful interaction between students and teachers in a larger community. It is because the effective communication that occurs through the social networking site is crucial for a successful learning process. By using the Facebook, the students can be assigned for tasks such as answering queries, extending in-class discussion and even they can announce upcoming fun learning events through live-stream feature which can enhance the active participation of learners in a big scale. Moreover, this online networks can enable educators provide instant feedback for the assigned tasks through this site in ease. On the other hand, students can avail virtual communities to learn from peers or instructors beyond classroom walls. Through this network site, students can also assist classmates or other learners who cannot understand a particular topic to review the lesson using the learning materials. This assistance pattern not only aimed to foster the students' learning experience but also contribute in enhancing teaching methodologies for interactive classroom learning.

Additionally, Facebook is known as a learning tool in line with a state that Facebook site is sensibly opted by students and pertain a stimulus of becoming a valuable resource to support their learning interaction and purposes. Harrison \& Thomas (2009) stated that social media can be utilized by learners to traverse new connections compared to simply sustaining existing relations, portioning to obtain a good comprehension of the complex processes of intercession involved in online learning community formation. Moreover, Ivala and Gachago 
(2012) adequate use of and Facebook groups in line with the motive to learn enhances students' active engagement in learning activities.

Alhomod \& Shafi (2012) examined that Facebook is a learning equipment in a communicative context which exhibit utilization at each stage of group-based learning for learners and enable to interact among each other. Moreover, Northcote \& Kendle (2001) urged that engaging in activities through online base such as conversing in online discussion boards and in pursuit of learning information may allow students to attain informal or formal learning skills adequately. Idris et al (2010) claimed that SNS enable language teachers expand learning beyond the classroom platform in which it would trigger reflective thinking, knowledge construction and promote English language learning to an optimum level. In line with this statement, it can be understood that Facebook social site has contributed in language learning which it ease the learners to use the widely-adopted site as the platform for effective language learning.

The interaction that occurs on Facebook social platform involve students in meaningmaking processes with authentic content and community. SNS customization based on individual needs and preferences ease students to participate in online discussions which aid them improve their language skills and knowledge. Thus, Facebook site is an elementary platform to promote useful interaction and valuable learning resources to serve learning purposes of optimal language learning. These researches merely recommended that Facebook site has a substantial impact when the features of Facebook site been utilized adequately for language learning purposes.

\section{Past Studies on using Facebook for Language Learning}

Many researches have been inquired to identify the contribution of Facebook in classroom learning. The significant interest and frequent engagements of students with SNS have aroused the focus of both academic scholars and instructors. Instructors indicates the involvement of social media into their classroom while researchers begin to inquire the effect of social media on students (Wu \& Hsu, 2011). Ismail et al (2019) titled "Student Perspectives on Using Social Media as Tools in Learning English" studied the element of flexibility, interactive and rich in resources in social media draw the promise to enhance student-centred learning. Students delineated that the continuum use of Facebook and its experiences has increased and enhanced their language skills, motivation, confidence and attitude concerning language learning experiences.

The rise of a new area of research has been fostered by social constructivist theories and the rapid expansion of technology in education. It is known as computer-assisted integrative learning which founded on students' interaction and knowledge construction using advanced-technology. This emerging discipline focuses on collaborative learning and draws on ideas such as social constructivism, social learning, blended learning theory and collaborative theory which prioritize group interaction and development of knowledge (Hmelo-Silver et al., 2008). Likewise, brisk evolution of social platform has piqued the attention of academic scholars from a range of contexts who want to learn more about social software and how it affects learning. Sakkir et al (2016) titled 'Students Perceptions of Social Media in Writing Classes at STKIP Muhammadiyah Rappang' examined students' acceptance about the utilization of social media in the English teaching process. Moreover, it added with 
Ziegler (2007) affirmed that Facebook has inhibited potential to positively encourage students as participatory learners in educational contexts.

Blattner \& Fiori (2009) stated Facebook can be applied to enhance learners' linguistic skills, boost their confidence, and encourage authentic language engagement. This study highlighted the features of Facebook and described how it can be used for language learning. They pointed out features of Facebook like sending and receiving private messages, creating groups, offering applications to attract chances for collaboration. In addition, the Facebook component has been defined as a pedagogical platform in ESL classroom for collaborative learning. This statement was supported Mahmud \& Ching (2012) about how Facebook could be utilized for educational reasons to prompt students' attitudes and perceptions of using this social networking site to improve their language learning in ESL settings. Yunus et al (2012) probed that Facebook group feature help to build individualized learning settings for writing. The goal of the research was to discover how students felt about using Facebook groups in ESL writing.

Ajjan \& Hartshorne (2008) stated that active Facebook users can enable them communicate and write effectively by participating in virtual conversations that take place in groups on the site. Mills (2009) identified that Facebook language learning seemed efficient because virtual social activities assist pupils improve their oral interaction skills in an authentic setting. Moreover, Shin (2011) employed Facebook as a model for peer evaluation, which resulted in a substantial increase in student interest and motivation to learn. Such a significant reaction suggested that social interactions on Facebook have a significant outcome on language learning environment.

McCarthy (2010) noted that students can communicate at their own leisure and study at their own pace in an online setting the language rather than spotted in classroom for immediate responses. Communication and connections initially were established in the simulating environment can be transmitted into the classroom. Birch et al (2007) stated that the online interaction among the users help to facilitate learning and provide opportunity for students to explore and gain knowledge in line with skills in a conducive environment at their own pace and time. They recommended that teachers can use Facebook as part of an educational initiative with a predetermined outcome in order to make the learning experience more relevant. In line it has become a part of students' lives, this Facebook site has a significant impact on their English learning performance. Moreover, Abu Bakar et al (2010) nurtured that Facebook establishes opportunities for students to interact and enhance their learning motivation.

Facebook can also be used to share and disseminate information among learners. The learners have acknowledged the effectiveness of using Facebook in learning provide quicker reference access to academic and learning supplies (Arteaga Sánchez et al., 2014). Moreover, the aforementioned studies partially explained the Facebook is commonly used as learning management system (LMS) with the motive to encourage greater participation and interaction when learning through site occurs. Yueh \& Hsu (2008) argued that LMS is a supportive learning tool for educators to employ informative activities such as exhibiting ideas, supervising course materials, and reviewing students' work either through online or hybrid mode. Wang et al (2012) employed a study in Singapore which prompted that Learners 
were generally satisfied with Facebook's core functions as an LMS despite prompting significant concerns about technological and privacy constraints. Another research proposed by Hurt et al (2012) posited exploitation of Facebook 'Groups' as instructional forum pertained better learning outcomes in learners. Additionally, Jong et al (2014) revealed that The Bulletin Board System was topped by Facebook and other e-platforms because the ease in exchange of educational materials, accessibility to study-related posts, and interactions between people.

A study posited by Yunus et al (2012) revealed Facebook sit as a source of strength in writing when participants adequately employ Facebook's features to be enlightened with new vocabulary through comments received from other students in the group, discussion to elicit writing task ideas, and spelling-review by peers. The study also proved that students can use Facebook to encourage them to accomplish their essays by actively indulging in Facebook 'group' discussion. The findings of this study also prompted that educators can implement instructional learning activities through social site such as Facebook with the purpose to develop more exciting and collaborative lessons. Moreover, the students were actively involved in exchanging ideas and thoughts one another through Facebook platform compared to standard teaching approaches in the classroom. In addition, the learners also stated that reading the group's remarks helped them to expand their vocabulary.

Shih (2013) investigated the effects of consolidating synthesized learning using Facebook and peer evaluation based English learning course for specific reasons which attempted by college students. The study stipulated that integrating Facebook in the English for Purposes (ESP) tool can accommodate learners to learn how to interact in business English contexts. Similarly, Bani-Hani et al (2014) contended Facebook group offers possibilities for students to enact instructions which essentially given outside of the classroom, therefore it leads to the enhancement of their writing abilities. Facebook groups also provide a multitude options for participants of the study in order to acquire and strengthen their writing abilities. Meanwhile, the study conducted by Mahmud \& Ching (2012) explains that incorporation of Facebook in ESL settings help to enhance learners' language learning. The findings proved that incorporation Facebook element greatly had enhanced students' language learning skills and improve their communication skill. Thus, it is evident that Facebook application has a high potential to improve and enhance learners' language learning.

\section{Past studies on Students' Perceptions of using Facebook in ESL Classroom}

Several studies have examined how Facebook site apparently affected language learning and how the use of Facebook bring changes in students' motivation, attitudes towards language learning. Eren (2012) explained students' attitudes in line with the exploitation of Facebook in language learning. The study comprised of 48 students who were engaged in an English-premium class and it was found that most of the students were active users of Facebook site. The result stipulated that students exhibit positive attitude toward using Facebook for academical reasons as well as to improvise linguistic skills. It is known that Facebook site plays a crucial role in enhancing learners' positive attitudes and perception about Facebook.

Moreover, Akbari et al (2012) probed students' attitudes and expectations of utilizing Facebook for language acquisition. According to the conclusion of the study, there is a 
considerable distinction between respondents' attitudes and the usages of Facebook site for learning reasons. In the pre-course questionnaire, a vast portion of responses regarded Facebook as supportive application for communication and knowledge sharing purposes. It is concluded that most of the students probed that Facebook pertain enormous potential to be used as formal educational tool after the completion of the course. Furthermore, the postcourse questionnaires demonstrated pupils' optimistic attitudes towards the efficacy of social networks uplifted. The similar study been proposed by Craig (2014) whom discovered the language learners ascertain the efficiency of specific pedagogical activities conducted on Facebook after the periodical course based on the application been conducted.

Besides, a study conducted by Friatin (2018) entitled 'Student Perceptions on Teaching Writing through Facebook Groups in EFL Class'. This case study examines teaching writing skill in EFL class Facebook groups which aimed to test students' perceptions of using Facebook groups in EFL writing. Qualitative descriptive with a closed questionnaire was used as a tool to examines the purpose of this study. The s study revealed students' opinions about the usage of Facebook groups in stimulating EFL writing showed a beneficial effect, namely the application of Facebook groups had a a significant influence on students, highly motivated, and made students happy in learning and developing writing skill in ease.

In the same ground to examine learners' perspectives about the exploitation of Facebook in ESL learning classroom, Lomicka and Lord (2009) reviewed the incorporation of technology into the language classroom revealed few ascends in the development in which it examines the potential benefits of using drawbacks of online-learning tool, the approaches proposed by educators to utilize the tool in classroom, examine students' insights and perceptions of utilizing Facebook as language learning tool. McLoughlin and Lee (2007) also delineated that it is fundamental to emphasize the affordance of Web 2.0, social software and additional instructional aids eventually anticipating the viewpoints and assumptions of Facebook site users. A similar study was conducted by Deng \& Tavares who explained that students tend to use Facebook for learning as they see it as a socialization and appealing learning functionalities within school settings. Students noted that Facebook as useful medium for information sharing, communicating ideas and learning strategies,analyzing a variety of academic and social concerns and gaining firm support for their learning. It appeared entirely normal to post stories, exchange thoughts or ideas and participate in online discussions on Facebook.

Junco (2012) cited that Facebook is employed by kids for academic purposes such as gathering and sharing information through links. The study resulted a positive educational outcome derived when it been utilized solely for socialization such as Facebook's status updates or chitchatting. A significant benefit pertained when students communicate or stroll website for learning purposes. By viewing instructor's website, the learners pertained a substantial rate of motivation and reliable learning. In recent time, Niu (2017) assessed 57 exploratory studies about Facebook's usage for educational reasons. The reviewed studies were classified into few groups as either teaching and learning tool, studies on learners' perception. The significant analysis depicted Facebook site's potential in formal teaching and learning situations. Merely, few studies were performed by Chugh and Ruhi (2018) who centered the use of Facebook in educational settings in order to identify its potential in educational platforms. Both reviews concluded that Facebook posited responses from 
learners as it helps to improve learning performances, student interaction and engagement in learning.

The number of Facebook site users reflecting it as the world's number one highly-used social media in accordance with the unlimited benefits pertained from this platform. The students presumed Facebook can empower and assist them to attain their roles in instructive organization, enhancing students' discourse and give clear instructions to complete the assigned tasks (Al-Dheleai et al., 2017). The findings of this study proposed Facebook as an encouragement to derive ideas to utilize it for educational aims. Hamat et al (2012) found different findings in the Malaysian context by where it was identified that $84 \%$ of learners in local settings converse and interact with their peers through social networking sites for learning reasons. Nevertheless, about 49.7 of students interact with academic scholars and instructors. The details of this study are identical with Wesseling's (2012) study. Therefore, Al-Dheleai and Tasir (2015) recommended the implementation of Facebook group feature in mean of communication for students promote interaction between students and instructor even without being Facebook 'friends' in the platform. The result of the study is obvious in which Facebook derives benefits to learners for learning motives.

Mazer et al (2007) claimed that students' learning enthusiasm and involvement were enhanced in great level through the engagement of course materials through SNS platforms such as Facebook and others. Yunus and Salehi's (2012) proposed a research which discovered reliable results that equate the stand made by Mazer et al. and Ziegler in terms of language learning through Facebook. He posited that the popularity of Facebook among young learners has been studied by the researchers which lead to proposal of various studies to investigate on how Facebook is used in learning path. He notified that understanding the reason why learners intend to use Facebook is crucial for the academic groups as it gives a huge influence on students' learning motivation, affective learning, and conducive classroom environment. In 2010, Gülnar et al have designed a scale to analyse the motives of Facebook site users. The study revealed that using Facebook had an impact on motivational variables of school students in Northern Cyprus.

Yunus and Salehi (2012) concluded language learners pertained higher determination and self consciousness through activities participation in line with Facebook usage. The result showed that learners mostly pertained positive responses about the elevation of their self motivation and confidence. Thus, the findings proved that Facebook's incorporation in language evoke positive effects on students' motivation and confidence. Shukor (2015) identified the 'comment' feature in the Facebook enable learners to assess peers' writing using the Facebook site and conveying their thoughts with other group members. This study proved that students were able to pick up new vocabulary, enhance their spellings, and acquire more useful suggestions and ideas. This feature intrigued them to be actively engaged in writing tasks because they might learn about useful information from 'comment' feature and improve meaningful communication with peers for their learning experience simultaneously.

Numerous researches demonstrated Facebook as a supportive tool for English language acquisition. According to Baran (2010), educators have the ability of accessing and administering Facebook groups to interchange knowledge by posting and giving comments in other members' posts. In line with this statement, learners acquire new vocabulary and their 
linguistic skills were developed. The instructional application of Facebook found motivated by Backer (2010) who also made a firm point like other researchers that Facebook should be known as an effective learning element. Çoklar (2012) posited that students found Facebook to be encouraging and intriguing in their learning. Shams (2014) inquired into the roles and efficiency of Facebook features in English language classrooms in Bangladesh. The findings of the study seemed a decline in direct class contact however it offsets motivation in learning and beneficial outcomes in regards to the use of Facebook remarkably for learners with poor linguistic skills' acquisition.

Shih (2011) backed up Yunus and Salehi's study which claimed Facebook as a base for blended learning and for peer-to-peer assessment impacted in increased student interest and engagement to develop their writing skill. Additionally,this study demonstrated that respondents were highly motivated and gained better language literacy towards learning theories opposed in effective reading strategies. Mills (2009) supported the utilization of Facebook site for learning reasons. The study probed that language learners were able to be productive with the employment of Facebook as beneficial platform to experience and engage with it. Her past studies prevailed that learners were able to immerse themselves in legit course environment using Facebook.

Furthermore, Kabilan et al (2010) administered a conditional study to scrutinize students' utilization of Facebook and its general views as an online English language learning platform. A set of questionnaire was designed to figure out their incitement, determination and attitudinal changes towards English language learning using Facebook. The findings showed that students nodded Facebook site as learning platform to learn English. Furthermore, Kabilan et al (2010) explained learners whom presumed their language abilities have been enhanced through the use of Facebook. In addition, their motivation and language learning attitudes were also strengthened through this implementation. This study indicated that Facebook site can assist the improvement in student confidence and enhances their engagement and satisfaction in language learning if it been utilized effectively. The researchers of this study spelled out that students' views and thoughts towards Facebook as learning base as to inculcate English learning attributed to authentic interaction and communication opportunities. Researchers presumed the use of Facebook would enable students to play the role as the masters of their own language acquisition with the assistance of other Facebook users and instructors.

Based on these affirmative perceptions and opinions pertained by the language learners, it can be summed that Facebook site has a great potential in enhancing optimal language learning for students. Additionally, both educators and learners can adapt the use of Facebook site for collaborative and academical purposes. Thus, this study aimed to scrutinize perceptions and attitudes of students using Facebook in ESL classroom as it is a communicative tool for English language learning.

\section{Methodology}

\section{Aim of the Research}

This study intended to explore students' perceptions of using Facebook in ESL classroom following by four item which is about general perception about language learning, perception of using Facebook, students' motivation, confidence level and attitude adapted from the study conducted by Atef ( 2015) which comprises similar elements in this current study. Based on the model of Facebook Educational Usage theoretical model (Mazman \& 
Usluel, 2010), the purpose of this survey is to discover ways of learners utilize Facebook site for their language learning based on few perspectives.

The survey instrument mainly designed to investigate how the students perceive about learning English using Facebook in ESL classroom following by four perspectives, which are perceptions, confidence, motivation and attitudinal changes of using Facebook. This study aimed to comprehend a view of what is intended to investigate in terms of using Facebook as supportive tool for language learning settings.

\section{Research Participants}

The study was conducted in an urban school located in Johor Bahru which it included year 6 students. The students were involved in a survey conduct which to explore students' perceptions of using Facebook in ESL classroom. For survey purpose, 30 randomly chosen participants who are the active Facebook account users were requested to participate in the survey. The researcher used online platform 'Google Form' to employ the questionnaire as it is not advisable to conduct the survey in face-to-face mode during the pandemic swirl.

\section{Research Instruments}

The instrument of this study was adapted from Abusa'aleek (2015) whom employed in his study to explore students' perceptions of English language learning in Facebook context. The instrument consists of 16 items and it is modified according to the suitability of the respondents of this study. The survey questionnaire is validated by a professional to employ validity and reliability data collection in this study.

The questionnaire sought into two parts, which the first section questioned about the demographic information and students' preferable language to use Facebook. On the other section, the questionnaire comprised items about their language usage, motivation, confidence level and attitude changes after the Facebook site employed in language learning classroom as in Appendix 1. The questionnaire was designed using the Likert-type scale which range from' Strongly disagree' to 'Strongly Agree' degree which ease respondents to answer the question items.

\section{Data Collection Procedure}

The following measures were taken during the research phase to achieve the during the research phase to achieve the primary goal of this research. Here is the procedure: To begin, respondents were circulated with the questionnaire about the study objective. The researcher requested respondents to complete a questionnaire about their perceptions of using Facebook in ESL classroom to improve language learning and also the development of students' motivation, confidence and attitude elements. The researcher evaluated the data collected through questionnaire to identify the possibilities brought through the usage of Facebook in this study.

\section{Findings and Discussion}

The findings of this study were conferred in three sections based on the survey questionnaire designed. The first part resembles about students' basic usage of length of using Facebook site. The second section of the questionnaire represents question items about Facebook as language learning tool that inculcates English language learning among school 
students. The last section examines students' perceptions of using Facebook in ESL classroom. This last section was divided into 3 parts which addresses motivational keys, confidence and learning attitudes among students.

\section{Students' basic usage and General Performance of Facebook Site}

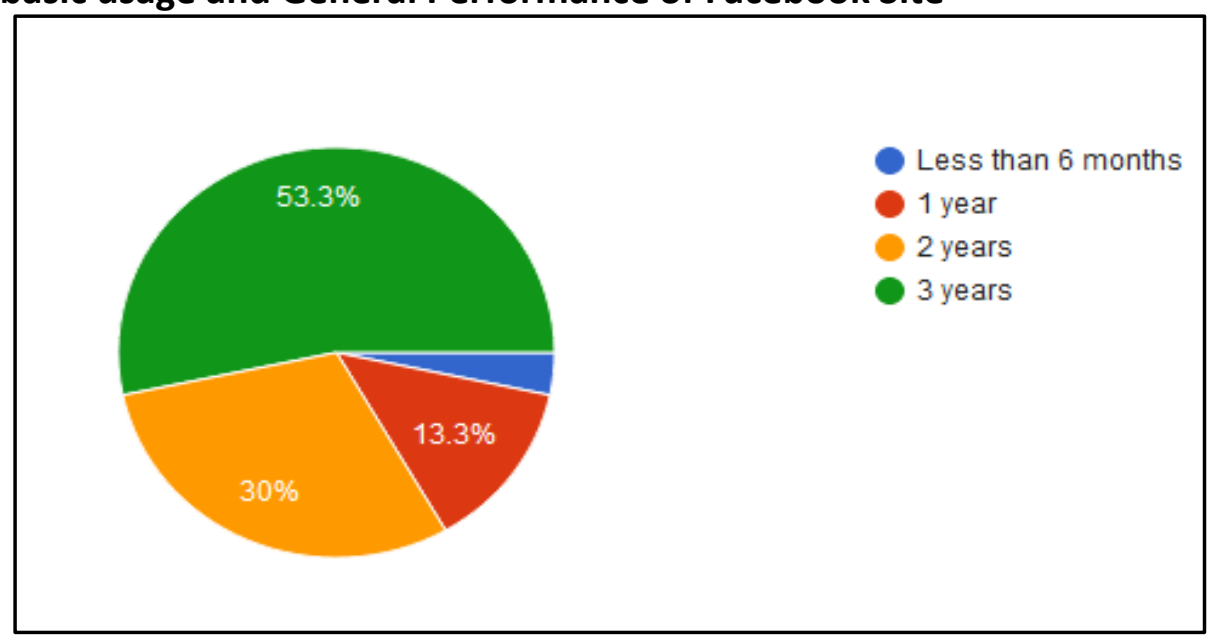

Table 1. Length of time as a Facebook user

\begin{tabular}{|l|l|l|l|l|l|}
\hline Year & $\begin{array}{l}\text { Less than } \mathbf{6} \\
\text { months }\end{array}$ & $\mathbf{1}$ & $\mathbf{2}$ & $\mathbf{3}$ & Total \\
\hline Frequency & 1 & 4 & 9 & 16 & 30 \\
\hline Percentage & $3.3 \%$ & $13.3 \%$ & $30 \%$ & $53.3 \%$ & $100 \%$ \\
\hline
\end{tabular}

Table 1 represents the responses of this study respondents based on the length of time owning the Facebook account. Based on the descriptive details, the majority of the students (83.3\%) owned a Facebook account more than two years duration. About $13.3 \%$ students stated that they owned a Facebook account merely for one year meanwhile $3.3 \%$ which only 1 student pertained to own the Facebook account for less than 6 months.

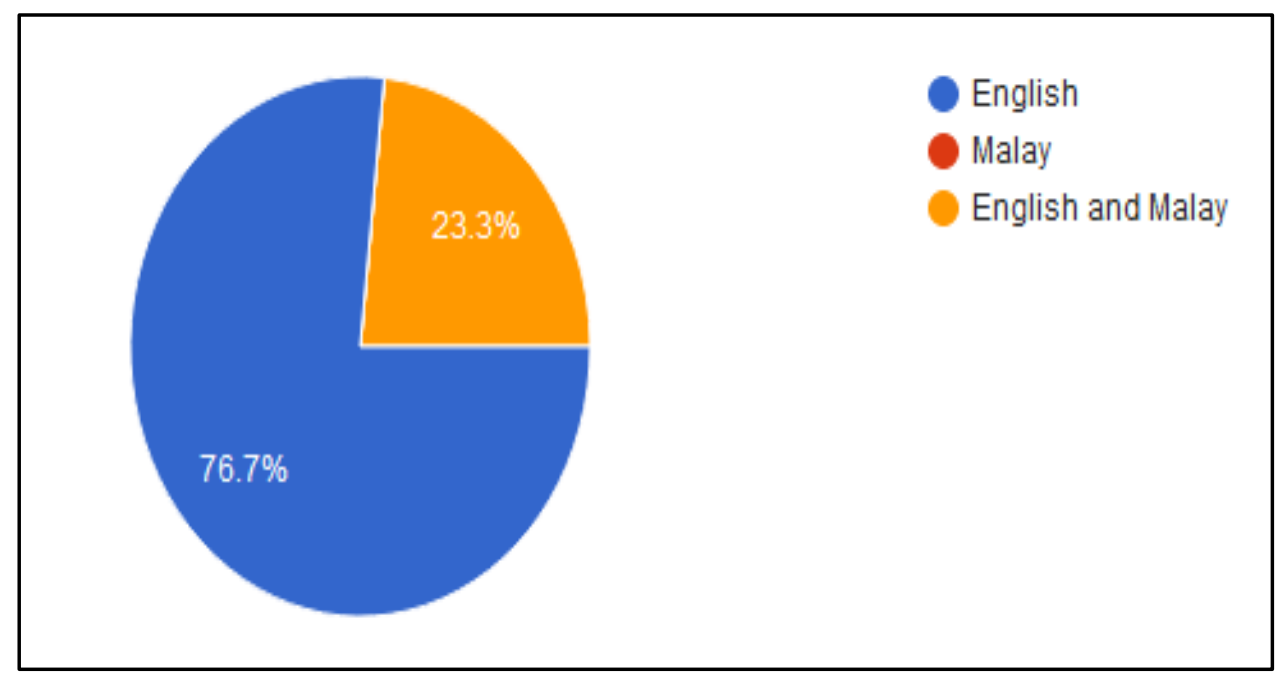


Table 2: Language used to Communicate in Facebook

\begin{tabular}{|l|l|l|}
\hline Language Used & Frequency & Percentage \\
\hline English & 23 & $76.7 \%$ \\
English and Malay & 7 & $23.3 \%$ \\
Malay & 0 & $0 \%$ \\
\hline
\end{tabular}

Table 2 above presents analytical data in regards to the language used by ESL students to interact and communicate in Facebook site. Based on the details above, about $76.7 \%$ students preferred to communicate using English language meanwhile $23.3 \%$ from the total number preferred to communicate using English and Malay in which Malay language considered as students' first language in the living community.

Table 3: Percentage of students logging into Facebook site

\begin{tabular}{|l|l|l|l|}
\hline & Daily & Weekly & Monthly \\
\hline Frequency & 19 & 9 & 2 \\
\hline Percentage & $63.33 \%$ & $30 \%$ & $6.66 \%$ \\
\hline
\end{tabular}

The table above shows the percentage of students logging into Facebook account in daily, weekly and monthly basis. About $63.33 \%$ which 19 students were logging into Facebook in daily basis while $30 \%$ ( 9 students) logging in weekly mode. Only 6.66\% ( 2 students) logging monthly once in Facebook account.

Facebook as learning tool to facilitate English language learning

Table 4: Facebook as learning tool to facilitate English language learning

\begin{tabular}{|c|c|c|c|c|c|c|}
\hline \multirow[b]{2}{*}{ No } & \multirow[b]{2}{*}{ Questions } & \multicolumn{5}{|c|}{ Students' Responses (\%) } \\
\hline & & $\begin{array}{l}\text { Strongly } \\
\text { Disagree } \\
\text { (1) }\end{array}$ & $\begin{array}{l}\text { Disagree } \\
(2)\end{array}$ & $\begin{array}{l}\text { Slightly } \\
\text { Agree } \\
\text { (3) }\end{array}$ & $\begin{array}{l}\text { Agree } \\
\text { (4) }\end{array}$ & $\begin{array}{l}\text { Strongly } \\
\text { Agree } \\
\text { (5) }\end{array}$ \\
\hline 1 & $\begin{array}{l}\text { I practice writing in } \\
\text { English via Facebook. }\end{array}$ & $3.33 \%$ & $3.33 \%$ & $16.66 \%$ & $30 \%$ & $46.66 \%$ \\
\hline 2 & $\begin{array}{l}\text { I practice reading in } \\
\text { English via Facebook. }\end{array}$ & $6.66 \%$ & $10 \%$ & $16.66 \%$ & $36.67 \%$ & $30 \%$ \\
\hline 3 & $\begin{array}{l}\text { Facebook enhances my } \\
\text { English } \\
\text { communication skills. }\end{array}$ & $0 \%$ & $3.33 \%$ & $6.66 \%$ & $46.66 \%$ & $43.33 \%$ \\
\hline 4 & $\begin{array}{l}\text { Facebook enhances my } \\
\text { confidence to write in } \\
\text { English. }\end{array}$ & $3.33 \%$ & $0 \%$ & $13.33 \%$ & $33.33 \%$ & $50 \%$ \\
\hline 5 & $\begin{array}{l}\text { Facebook helps me to } \\
\text { overcome language } \\
\text { mistakes. }\end{array}$ & $10 \%$ & $3.33 \%$ & $13.33 \%$ & $33.33 \%$ & $40 \%$ \\
\hline 6 & $\begin{array}{l}\text { I learn new words in } \\
\text { English via Facebook }\end{array}$ & $3.33 \%$ & $3.33 \%$ & $13.33 \%$ & $46.67 \%$ & $33.33 \%$ \\
\hline
\end{tabular}


Table 4 above explains how ESL students pertained Facebook site as language learning tool which help to facilitate and encourage English language learning which in line it contributes to the development of language skills. The majority of the students which about $76.66 \%$ abbreviated from the degree of 'strongly agree' to 'agree' concurred Facebook site can be utilized to improve their English writing ability, meanwhile about $66.67 \%$ students acknowledged that Facebook site can lead students to practice their reading skill.

Furthermore, the students also believed that Facebook site enhances their communication skills. 83.33\% students stated that Facebook can become as an effective learning environment. $73.33 \%$ students agreed that Facebook site helps the students to overcome language mistakes that made by them and about $79.99 \%$ of students concurred that Facebook site enable them to learn new words in English.

Based on the responses pertained by students regarding the perceptions of using Facebook site for language learning, it can be foreseen that Facebook site helps to promote self-reliance quality among students which it would lead them to improve their language proficiency and acquire authentic learning content from synchronous communication through Facebook.

\section{Students' perceptions and learning attitudes of using Facebook in ESL}

Classroom

Table 5: Facebook enhancing students' motivation

\begin{tabular}{|c|c|c|c|c|c|c|}
\hline \multirow[b]{2}{*}{ No } & \multirow[b]{2}{*}{ Questions } & \multicolumn{5}{|c|}{ Students' Responses (\%) } \\
\hline & & $\begin{array}{l}\text { Strongly } \\
\text { Disagree } \\
\text { (1) }\end{array}$ & $\begin{array}{l}\text { Disagree } \\
\text { (2) }\end{array}$ & $\begin{array}{l}\text { Slightly } \\
\text { Agree } \\
\text { (3) }\end{array}$ & $\begin{array}{l}\text { Agree } \\
\text { (4) }\end{array}$ & $\begin{array}{l}\text { Strongly } \\
\text { Agree } \\
\text { (5) }\end{array}$ \\
\hline 1 & $\begin{array}{l}\text { Facebook increases my } \\
\text { motivation to speak } \\
\text { using English with peers. }\end{array}$ & $0 \%$ & $6.66 \%$ & $13.33 \%$ & $46.67 \%$ & $33.33 \%$ \\
\hline 2 & $\begin{array}{l}\text { Facebook increases my } \\
\text { motivation to read } \\
\text { English materials. }\end{array}$ & $3.33 \%$ & $6.67 \%$ & $10 \%$ & $43.33 \%$ & $36.66 \%$ \\
\hline 3 & $\begin{array}{l}\text { Facebook increases my } \\
\text { motivation to write in } \\
\text { English. }\end{array}$ & $0 \%$ & $6.67 \%$ & $6.67 \%$ & $36.66 \%$ & $50 \%$ \\
\hline
\end{tabular}

Table 5 above shows in general that Facebook had enhanced students' motivational attitude to learn English language through Facebook. The result shows that $79.99 \%$ of students ( abbreviated from the degree of 'strongly agree' to 'agree') admitted the statement that Facebook site has increased their motivation to speak using English with their peers, meanwhile $79.99 \%$ too expressed their opinion that Facebook had increased their motivation to read English learning materials in Facebook site. Moreover, about $86.66 \%$ stated that Facebook site also increased their motivation to write in English language better.

Table 6 below shows the responses of students regarding students' confidence level in learning English. 
Table 6: Facebook enhancing students' confidence level in using English

\begin{tabular}{|c|c|c|c|c|c|c|}
\hline \multirow[b]{2}{*}{ No } & \multirow[b]{2}{*}{ Questions } & \multicolumn{5}{|c|}{ Students' Responses (\%) } \\
\hline & & $\begin{array}{l}\text { Strongly } \\
\text { Disagree } \\
\text { (1) }\end{array}$ & $\begin{array}{l}\text { Disagree } \\
\text { (2) }\end{array}$ & $\begin{array}{l}\text { Slightly } \\
\text { Agree } \\
\text { (3) }\end{array}$ & $\begin{array}{l}\text { Agree } \\
\text { (4) }\end{array}$ & $\begin{array}{l}\text { Strongly } \\
\text { Agree } \\
\text { (5) }\end{array}$ \\
\hline 1 & $\begin{array}{l}\text { It enhances my confidence } \\
\text { level to write in English. }\end{array}$ & $3.33 \%$ & $10 \%$ & $10 \%$ & $46.66 \%$ & $30 \%$ \\
\hline 2 & $\begin{array}{l}\text { It enables me to read } \\
\text { English materials. }\end{array}$ & $0 \%$ & $10 \%$ & $10 \%$ & $46.66 \%$ & $33.33 \%$ \\
\hline 3 & $\begin{array}{l}\text { It enhances my confidence } \\
\text { level to communicate using } \\
\text { English. }\end{array}$ & $0 \%$ & $6.66 \%$ & $13.33 \%$ & $43.33 \%$ & $36.66 \%$ \\
\hline
\end{tabular}

Table 6 presents the data about how Facebook site has enhanced students' confidence in learning English. $76.66 \%$ students pertained that Facebook site had boost their confidence level to write in English, while $79.99 \%$ students believed that Facebook enabled them to read authentic English materials offered through various Facebook pages. In line with their communication ability, $79.99 \%$ students agreed it also enhanced their confidence level to interact using English with others through Facebook site.

\section{Table 7: Students' attitude towards learning English using Facebook}

Table 7 above represents the data regarding students' responses about their perceptions how Facebook site has improved their learning attitudes towards learning English using Facebook site. The study's result in overall shows that students have exhibited positive

\begin{tabular}{|l|l|l|l|l|l|l|}
\hline \multirow{2}{*}{ No } & Questions & \multicolumn{3}{|l|}{ Students' Responses (\%) } \\
\cline { 3 - 8 } & $\begin{array}{l}\text { Strongly } \\
\text { Disagree } \\
\text { (1) }\end{array}$ & Disagree & $\begin{array}{l}\text { Slightly } \\
\text { Agree } \\
\text { (2) }\end{array}$ & Agree & $\begin{array}{l}\text { Strongly } \\
\text { Agree } \\
\text { (3) }\end{array}$ \\
\hline $\mathbf{1}$ & $\begin{array}{l}\text { Learning English using } \\
\text { Facebook makes learning } \\
\text { English more interesting. }\end{array}$ & $0 \%$ & $3.33 \%$ & $6.66 \%$ & $40 \%$ & $50 \%$ \\
\hline $\mathbf{2}$ & $\begin{array}{l}\text { I have positive attitudes } \\
\text { towards learning ESL via } \\
\text { Facebook. }\end{array}$ & $3.33 \%$ & $3.33 \%$ & $10 \%$ & $43.33 \%$ & $40 \%$ \\
\hline $\mathbf{3}$ & $\begin{array}{l}\text { The use of Facebook } \\
\text { makes learning English } \\
\text { easier. }\end{array}$ & $0 \%$ & $0 \%$ & $13.33 \%$ & $36.66 \%$ & $50 \%$ \\
\hline $\begin{array}{l}\text { Facebook encourages me } \\
\text { to spend more time in } \\
\text { learning English. }\end{array}$ & $0 \%$ & $6.66 \%$ & $10 \%$ & $30 \%$ & $53.33 \%$ \\
\hline
\end{tabular}

learning attitudes towards learning English using Facebook site. Most of the students with the percentage of $90 \%$ agreed that Facebook site helped them to learn English in smooth and it makes their learning more interesting. Moreover, $83.33 \%$ of students stated that they 
pertained positive attitudes towards English language learning via Facebook site. In addition, most of the students ( $86.66 \%$ ) believed that Facebook site also ease their English learning process. As the last time, about $83.33 \%$ agreed that Facebook site encourages them to spend more time to learn English through posts and learning materials offered in the site.

Based on the detailed description of this study, it can be found that Facebook plays its part in enhancing language skills. This research underpinned Facebook platform likely to explore students' discernment and perceptions about the use of Facebook in ESL classroom learning. The researcher have been pointed with discovering information regarding the efficacy of Facebook site in educational proportion and seek strongest support for whichever action they decide in the basis of classroom learning. Moreover, as it claimed in previous studies this study also presumed Facebook as popular and highly used social site which promotes interaction and communication with others in line to enhance linguistic abilities. This social site has the base to offer a range of opportunities for users to share knowledge and develop communication skills with community. Moreover, it also proved that Facebook site also increases students' motivation to learn English through Facebook. As in general, this Facebook site also has potentials to promote motivation and self confidence among language learners in learning English as well it affects learners' learning attitudes through Facebook to positive side.

\section{Conclusion}

Facebook is known as a learning tool in line with a state that Facebook site is sensibly opted by students and pertain a stimulus of becoming a valuable resource to support their learning interaction and purposes. It is a popular social site among language learners which pertains tendency to promote language learning in ESL classroom. Facebook site is also a base that provide learning opportunities for learners without limitation. Facebook can be propped as a tool to improve students' linguistic abilities, enhance motivation and confidence level as in line can promote authentic language practice with peers or Facebook users. Interactions occur through Facebook platform can facilitate self-reliance motive in learning as it also provide opportunities for students to enhance and learn information regarding language learning in ease.

Based on the aforementioned conducted by researchers, the perspective views comprehended that language learning is feasible for learners. In line with the technologies that prop up Facebook site and its features characterizes that Facebook has the ability to engage students in a meaningful language-based interaction even though the initial intention of being a part in Facebook is to communicate and interact for the purpose of exchanging information, maintaining relationships or to find valuable resources for learning. The appropriate utilization and association of Facebook in educational learning would be able to facilitate and involve language learners in meaningful learning within an online community. This statement is strongly supported by Kabilan et al. (2010)whom shared the idea that Facebook and its unique features can be utilized as educational tool in order to involve English language learners in an online learning community.

The result of this study portrays that students whom are Facebook account users concurred that Facebook is an effective and easily accessible tool which in conjunction it promotes and encourages English language learning in ESL classroom. Moreover, they 
believed that Facebook site has develop positive attitudes in themselves in learning English language. It is also believed Facebook site has potentials to enhance learners' linguistic abilities, self motivation and confidence level in learning English language.

Based on the findings of the study, it is proved that Facebook medium has positive perception and contribution for learning English in existing society. It plays role as an endless tool which supports students to learn and practice English language skills in an effective way. Furthermore, this Facebook medium leads a way to increase their knowledge in utilizing the features in it to maximize their language learning. Facebook medium also creates a stressfree environment for students to be comfortable and motivated to learn English either inside or outside of the school. As it known widely that Facebook is a communication and an engagement tool, teachers can utilize this social media platform to provide authentic resources of learning through its features which make students to be more engaged towards the lesson learning. In conclusion, the future researchers can explore more impact of Facebook medium to enhance English language skills and how it can minimize challenges and issues from the usage of social media for learning English.

\section{References}

Abu Bakar, N., \& Latif, H. (2010). ESL Students feedback on the use of blogs for language learning. 3L: Language, Linguistics, Literature, 16(1), 120-141.

Abusa'aleek, A. O. (2015). Students' perceptions of english language learning in the Facebook context. 15. 60-75.

Al-Dheleai, Yahya, Tasir, Z. (2017). Using facebook for the purpose of students' interaction and its correlation with students' academic performance. Turkish Online Journal of Educational Technology. 16. 170-178.

Ajjan, H., \& Hartshorne, R. (2008). Investigating faculty decisions to adopt Web 2.0 technologies: theory and empirical tests. The Internet and Higher Education, Vol. 11, No. 2, pp. 71-80.

Akbari, E., Eghtesad, S., \& Simons, R. J. (2012). Students' attitudes towards the use of social networks for learning the English language. Retrieved on July $2^{\text {nd }} 2020$ from http://conference.pixelonline.net/ICT4LL2012/common/

Alhomod, S. M., \& Shafi, M. M. (2012). Best practices in e-government: A review of some innovative models proposed in different countries. International Journal of Electrical \& Computer Sciences, 12(1), 1-6

Al -Munawwarah, S. F. (2014). Teachers' perceptions on the use of ICT in Indonesian EFL learning context. English Review: Journal of English Education, 3(1), 70-80.Retrieved from https://www.journal.uniku.ac.id/index.php/ERJEE/article/viewFile/116/78

Aydin, S. (2012). A Review of Research on Facebook as an Educational Environment. Educational Technology Research and Development. 60. 10.1007/s11423-012-9260-7.

Bani-Hani, N., Al-Sobh, M., \& Abu-Melhim. (2014). Utilizing Facebook Groups in Teaching Writing: Jordanian EFL Students' Perceptions and Attitudes.International Journal of English Linguistics, 4 (5).

Baran, B. (2010). Facebook as a formal instructional environment. British Journal of Educational Technology, 41(6), 146-149.

Blattner, G., \& Fiori, M. (2009). Facebook in the language classroom: Promises and possibilities International Journal of Instructional Technology and Distance Learning, 6, 17-28. 
Buzzetto-More, N. A. (2012). Social networking in undergraduate education. Inter disciplinary Journal of Information, Knowledge, and Management, 7, 63-90.

Birch, D., \& Volkov, M. (2007). Assessment of online reflections: Engaging English second language (ESL) students. Australasian Journal of Educational Technology, 23(3), 291306.

Boyd, D. M., \& Ellison, N. B. (2007). Social Network Sites: Definition, History, and Scholarship. Journal of Computer-Mediated Communication, 13(1), 210-230.

Chugh, R., \& Ruhi, S. (2018). Social media in higher education: A literature review of Facebook. Education and Information Technologies,23,605-616

Çoklar, A. N. (2012). Evaluations of students on Facebook as an educational environment. Turkish Online Journal of Qualitative Inquiry, 3(2), 42-53

Dabbagh, N., \& Kitsantas, A. (2012). Personal learning environments, socialmedia, and selfregulated learning: A natural formula for connecting formal and informal learning. Internet and Higher Education, 15(1), 3-8.

Ehsan, N., \& Nasri, M. (2019). The impact of social media on EFL learners" speaking skill. Journal of Applied Linguistics and Language Research, 6(3), 1-17.

Eren, Ö. (2012). Students' attitudes towards using social networking in foreign language classes: A Facebook example. International Journal of Business and Social Science, 3(20), 288-294.

Facebook. (2011). Statistics: people on Facebook. Retrieved on July 8, 2011 from https://www.Facebook.com/press/info.php/statistics.

Friatin, L. (2018). Students' Perception in Teaching Writing through Facebook Group in EFL Class. Journal for Language and Foreign Language Learning. Volume7. 57-66.

García-Domingo, M., Aranda, M., \& Fuentes, V. M. (2017), 'Facebook use in university students: Exposure and reinforcement search', Procedia - Social and Behavioral Sciences 237, 249-254. Retrieved fromhttps://doi.org/10.1016/j.sbspro.2017.02.071

Guedes., E., Sancassiani, F., Cartam, M. G., Campos, C., Machado, S., King, A. L. S., Nardi, A. E. (2016) Internet Addiction and Excessive Social Networks Use: What About Facebook?, ClinPractEpidemiol Mental Health,12,pp.43-48. d 10.2174/1745017901612010043.

Gülnar, B., Balco, U., \& Cakor, V. (2010). Motivations of Facebook, You Tube and Similar Web Sites Users. Ahmet Yesevi University Board of Trustees, Volume 54,161-184.

Hamat, A., Embi, M. H., Haslinda, A. H. (2012). The Use of Social Networking Sites among Malaysian University Students. The International Journal of Learning. Volume 18, Issue 7, 153-164.

Harrison, R., \& Thomas, M. (2009). Identity in online communities: Social networking sites and language learning. International Journal of Emerging Technologies and Society, Vol. 7, No. 2, 109-124.

Haverback, H. R. (2009). Facebook: Uncharted territory in a reading education classroom. International Education Studies. Volume 5 (3), page 56. Retrieved from http://search.proquest.com/docview/223418449?accountid=30906.

Hmelo-Silver, C. E., Chernobilsky, E., Jordan, R. C. (2008). Understanding collaborative learning processes in new learning environments. Instructional Science. 36 (5). 409-430. 10.1007/s11251-008-9063-8.

Hurt, N. E., Moss, G. S., Bradley, C. L., Larson, L. R., Lovelace, M., Prevost, L. B., Camus, M. S. (2012). The 'Facebook'effect: college students' perceptions of online discussions in the age of social networking. International Journal for the Scholarship of Teaching and Learnin., Volume 6, No. 2. doi:https://doi.org/10.20429/ijsotl.2012.060210 
Idris, H., \& Ghani, R. A. (2012). Construction of knowledge on facebook. 3L: The Southeast Asian Journal of English Language Studies. Vol 18(3): 61 - 72

Inayati, N. (2015). English language teachers" use of social media technology in Indonesian higher education context. Asian EFL Journal Research Articles. Vol. 17 No.4.

Ismail, S., Marhamah, M., Zaim, M., Mukhaiyar, M. (2019). Student Perspective in Using Social Media As a Tool in English Language Learning. Journal of English for Academic. 6. 58. 10.25299/jshmic.2019.vol6(1).2603.

Junco, R. (2012). Too much face and not enough books: The relationship between multiple indices of Facebook use and academic performance. Computers in Human Behavior, 28(1), 187-198.

Jong, B. S., Lai, C., Hsia, Y., Lin, T. W., \& Liao, Y. (2014). An exploration of the potential educational value of Facebook. Computer of Human Behaviour. Volume 32, 201-211.

Kabilan, M. K., Ahmad, N., \& Abidin, M. J. Z. (2010). Facebook: An online environment for learning of English in institutions of higher education?. Internet and Higher Education, 13(4), 179-187. Elsevier Ltd. Retrieved June, 2021

from https://www.learntechlib.org/p/108382/.

Lomicka, L., \& Lord, G. (2009). Introduction to social networking, collaboration, and web 2.0 tools. The next generation: Social networking and online collaboration in foreign language learning. University of South CarolinaThe Routledge Handbook of Language Learning and Technology. 255-268

Mazman, S. G., Usluel, Y. K. (2009). The usage of social networks in educational context. International Journal of Behavioral, Cognitive, Educational and Psychological Sciences, 1(4). 224-228.

Mazman, S. G., \& Usluel, Y. K. (2010). Modeling educational usage of Facebook. Computers \& Education, 55(2), 444-453. doi:10.1016/j.comp.edu..2010.02.008.

Mathew, P., Job, L. M., Damen, T. A., \& Islam, M. R. (2013). An Arab EFL context: Does variance in anxiety and motivation across gender impact language attainment? Studies in Literature \& Language. Volume 6(3), 14-22.

Mazer, J., Murphy, R., \& Simonds, C. (2007). I'll see you on 'Facebook': The effects of computer-mediated teacher self-disclosure on student motivation, affective learning, and classroom climate. Communication Education, 56(1), 1-17.

McCarthy, J. (2010). Blended learning environments: Using social networking sites to enhance the first year experience. Australasian Journal of Educational Technology, Volume 26(6), 729-740.

McLoughlin, C., \& Lee, M. J. W. (2007). Social software and participatory learning: Pedagogical choices with technology affordances in the Web 2.0 era. In ICT: Providing choices for learners and learning.Retrieved on July 2021 from

http://www.ascilite.org.au2008/conferences/singapore07/procs/mcloughlin.pdf

Mills, N. A. (2009). Facebook and the use of social networking tools to enhance language learner motivation and engagement. Paper presented at the Northeast Association for Language Learning Technology (NEALLT) Conference, Yale University, New Haven, CT, 30-31 October.

Mills, N. A. (2009). Facebook and the use of social networking tools to enhance language learner motivation and engagement. Northeast Association for Language Learning Technology (NEALLT) Conference, Yale University, New Haven.

McLoughlin, C., \& Lee, M. J. (2007, December). Social software and participatory learning: Pedagogical choices with technology affordances in the Web 2.0 era. In ICT: Providing 
choices for learners and learning. Centre for Educational Development, Nanyang Technological University. 664-675.

$\mathrm{Niu}$, L. (2017). Using Facebook for academic purposes: Current literature and directions for future research. Journal of Educational Computing Research. Advance Online Publication. Vol 56(8):1384-1406.

Northcote, M., \& Kendle, A. (2001). Informal online networks for learning: Making use of incidental learning through recreation. Australian Association for Research in Education (AARE) International Conference. Retrieved from

http://ro.ecu.edu.au/ecuworks/4882/.

Sakkir, G., Rahman, Q., Salija, K. (2016). Students' Perception on Social Media in Writing Class at STKIP Muhammadiyah Rappang, Indonesia. International Journal of English Linguistics. Volume 6 (3). 170.

Shams, S. (2014). Efficacy of Online Social Networks on Language Teaching: A Bangladeshi Perspective. IAFOR Journal of Education, 2(2), 117-147

Shin, D. S. (2018). Social media \& English learners" academic literacy development. Multicultural Education, 25(2), 13-16.

Shih, R.-C. (2011). Can Web 2.0 technology assist college students in learning English writing? Integrating "Facebook" and peer assessment with blended learning. Australasian Journal of Educational Technology, 27(5), 829-845.

Shih, R. C. (2013). Effect of using Facebook to assist English for business communication course instruction. TOJET, 12(1).52-59 Retrieved from http://eric.ed.gov/?id=EJ1008867.

Shukor, S. (2015). ESL Students' Perceptions on The Use of Facebook as A Collaborative Writing Tool in Improving Writing Performance. Journal of Nusantara Studies 2017, Vol 2(1) 177-193.

Wang, Q., Woo, H. L., Quek, C. L., Yang, Y., \& Liu, M. (2012). Using the Facebook group as a learning management system: An exploratory study. British Journal of Educational Technology, 43(3), 428-438.

Wesseling, N. (2012). How Students Use Facebook. WEI International AcademicConference Proceedings. 20-25.

Wu, P. \& Hsu, L. H. (2011). EFL learning on social networking site?: An action research on Facebook. Teaching \& Learning with Vision Conference. Retrieved April 3,2021, from http://tlvconf.files.wordpress.com/2011/04/tlv-paper-wu.pdf.

Yueh, H.-P., \& Hsu, S. (2008). Designing a learning management system to support instruction. Communications of the ACM, 51(4), 59-63.

Yunus, M., Salehi, H., Sun, C., Yen, J., \& Li, L. (2011). Using Facebook groups in teaching ESL writing. Recent Researches in Chemistry, Biology, Environment and Culture,75(1),7580. Retrieved on July 2021, from https://www.wseas.us/elibrary/conferences/2011/Montreux/COMICICBIO/COMICICBI 0-11.pdf.

Yunus, M. M., Salehi, H., \& Chenzi, C. (2012). Integrating social networking tools into ESL writing classroom: Strengths and weaknesses. English Language Teaching, Volume 5(8), 42-48. 